J. Amer. Soc. Hort. Sci. 115(2):298-301. 1990.

\title{
Relationship of Porphobilinogen Deaminase Activity to Chlorophyll Content and Fruit Development in 'Heinz 1350' Tomato
}

\author{
Robert W. McMahon ${ }^{1}$, Cecil R. Stewart ${ }^{2}$, and Richard J. Gladon ${ }^{3}$ \\ Department of Horticulture, Iowa State University, Ames, IA 50011 \\ Additional index words. enzymes, pigments, high-performance liquid chromatography, Lycopersicon esculentum \\ Abstract. Chlorophyll $\boldsymbol{a}$ and $\boldsymbol{b}$ contents were determined in developing tomato fruit (Lycopersicon esculentum Mill. \\ 'Heinz 1350') at 5-day increments from 10 or 15 days past anthesis to fully ripe ( 55 to 60 days). When presented on \\ a whole-fruit basis, chlorophyll $a$ and b contents increased from 15 days past anthesis to 35 days and then decreased \\ to zero at 55 days. Porphobilinogen (EC 4.2.1.24; PBG) deaminase activity was measured in extracts from the fruit, \\ and changes in PBG deaminase activity correlated with changes in chlorophyll and protein contents with respect to \\ fruit age. Partial characterization of tomato PBG deaminase enzyme showed similarities to PBG deaminase enzymes \\ isolated from other sources.
}

The light-controlled regulation of the early steps of chlorophyll biosynthesis is well-documented (Castelfranco and Beale,

Received for publication 29 Jan. 1987. Journal Paper no. J-11649 of the Iowa Agricultural and Home Economics Experiment Station, Ames. Project no. 2347. Research taken from a dissertation by R.W.M. in partial fulfillment of the requirements for a $\mathrm{PhD}$ degree in horticulture and botany. Financial support by the Iowa State Univ. Research Foundation is gratefully acknowledged. The cost of publishing this paper was defrayed in part by the payment of page charges. Under postal regulations, this paper therefore must be hereby marked advertisement solely to indicate this fact.

'Assistant Professor, The Ohio State Univ. Agricultural Technical Institute, Wooster, OH 44691.

${ }^{2}$ Professor, Dept. of Botany.

${ }^{3}$ Associate Professor. To whom reprint requests should be addressed.
1983; Harel, 1978). A study by Frydman and Frydman (1979) suggested that there may be a control point of chlorophyll biosynthesis related to the age of the plant tissue. PBG deaminase is one of the enzymes of the chlorophyll biosynthetic pathway that functions, with uroporphyrinogen (UROGEN) III cosynthase, in transforming four molecules of PBG into one molecule of UROGEN III. PBG deaminase activity was high in extracts from young leaves of pepper and poinsettia, low in extracts from mature leaves, and almost nil in extracts from senescent leaves (Frydman and Frydman, 1979). UROGEN III cosynthase, however, showed no changes in activity in extracts from the three ages of leaves. Frydman and Frydman (1979) concluded that 
PBG deaminase may control chlorophyll biosynthesis, reaching maximum activity when the chlorophyll content of the leaf is high and then rapidly diminishing in activity with the resultant loss of chlorophyll from the leaf tissue. In addition, Brodie et al. (1977) suggested that PBG deaminase also may play a role in regulating heme biosynthesis.

The purposes of this research were to measure changes in chlorophyll content and PBG deaminase activity during tomato fruit development and to determine if the changes were similar in pattern. Some characteristics of the PBG deaminase enzyme also were determined.

\section{Materials and Methods}

Plant materials. 'Heinz 1350' tomato plants were grown in an environmentally controlled greenhouse by using standard cultural practices. Plants were trained to a single stem, and replicates of fruit of the same physiological and chronological age were obtained by the procedure of Lyons and Pratt (1964). Developmental stages and chronological age of these fruits corresponded to the stages and visual appearance described by Martin et al. (1979).

Chemicals. PBG and uroporphyrin (URO) I and III standards were purchased from Porphyrin Products (Logan, Utah). Polyvinylpolypyrrolidone (PVPP), Tris buffer, bovine serum albumin, N-ethylmaleimide, and p-chloromercuribenzoate were obtained from Sigma. All other chemicals purchased from commercial sources were reagent grade.

Extraction and quantitation of chlorophyll. Procedures for harvesting the fruit, extracting chlorophyll from the fruit tissue, and quantitation of chlorophyll by high-performance liquid chromatography (HPLC) were described by McMahon and Gladon (1984).

Enzyme extraction. Three replicates, each consisting of four fruits, were harvested at 5-day intervals during fruit development (10 or 15 days past anthesis to full ripeness at 55 to 60 days). Immediately after harvest, replicates of fruits were placed in ice and chilled for $1 \mathrm{hr}$. Each replicate was weighed, and a core of tissue (1 cm in diameter) was removed from the axis of each fruit with a stainless steel cork borer, weighed, and prepared for extraction.

Cores were diced and thoroughly ground in a cold (4C) mortar in $40 \mathrm{ml}$ of $10 \mathrm{mM}$ Tris, $\mathrm{pH} 7.0$. Before grinding, $1.25 \mathrm{~g}$ of $\mathrm{PVPP} / \mathrm{g}$ fresh weight of tissue was added to the grinding medium to prevent phenolic browning of fruit cores that were 15 days or more past anthesis. However, it was necessary to use $5.0 \mathrm{~g}$ of PVPP/g fresh weight of 10-day-old fruit tissue because of its higher phenolic content (Hobson, 1967; Mayer and Harel, 1981). Each homogenate was filtered through four layers of cheesecloth and centrifuged at $500 \times g$ for $5 \mathrm{~min}$. The pellet was discarded and the supernatant was centrifuged at 100,000× $\mathrm{g}$ for $1 \mathrm{hr}$. The pellet was discarded, and the supernatant was used as the enzyme source. Protein content of the extract was determined by the Bradford (1976) method.

Enzyme assay. The standard reaction mixture for all assays consisted of $1 \mathrm{ml}$ of $30 \mathrm{mM}$ Tris, PBG, and $1 \mathrm{ml}$ of extract in a total volume of $2.15 \mathrm{ml}$. The final concentration of PBG was $102 \mu \mathrm{M}$, and the $\mathrm{pH}$ of this mixture was 8.0. The mixture was incubated in the dark for $1 \mathrm{hr}$ in a 37C water bath with gentle shaking. Biosynthesized UROGEN was oxidized to URO according to the method of Jordan and Shemin (1973), and URO was measured spectrophotometrically at $405 \mathrm{~nm}$. Identification of URO was by comparison of absorption spectra with standard
URO. To separate URO I and III isomers by HPLC, a Waters Associates $\mu$ Bondapak- $\mathrm{C}_{18}$ reverse-phase analytical column (3.9 $\mathrm{mm}$ id. $\times 30 \mathrm{~cm}$ ) with isocratic elution using phosphate buffer (flow rate of $1 \mathrm{ml} . \mathrm{min}^{-1}$ ) was used (Englert et al., 1979; Wayne et al., 1979). URO isomers were detected with a Schoeffel FS 970 fluorometer set as follows: range $=0.1 \mu \mathrm{A}$, sensitivity $=$ 530, time constant $=6$ see, high-signal suppression, excitation wavelength $=230 \mathrm{~nm}$, and an emission wavelength $=389$ $\mathrm{nm}$. URO isomers were identified by comparing their retention times and cochromatography with the URO isomer standards.

\section{Results}

Effect of fruit age. When presented on a whole-fruit basis, PBG deaminase activity, chlorophyll content, and protein content increased to a maximum in 35-day fruits (Fig. 1 A-C). Chlorophyll content then decreased to zero in 55-day fruits, whereas PBG deaminase activity diminished to a very low level in 55- and 60-day fruits. The growth rate of the fruits (Fig. 1D) was high between days 25 and 45, with the maximum at $=35$ days. Subsequently, the protein content fell to zero in 60-day fruits, and the growth rate approached zero as the fruit matured.

The PBG deaminase activity of 15-day-old fruit was 4.59 nmol URO/hr, while the activity from ripe fruit (60 days past anthesis) was $0.15 \mathrm{nmol} \mathrm{URO} / \mathrm{hr}$. When extracts from each of these ages of fruit were mixed in equal volumes, the resultant PBG deaminase activity was about additive $(2.30 \mathrm{nmol}$ URO/ hr). Similar results were obtained when extracts from 15-day fruits were mixed with those from tomatoes at the breaker and pink stages of ripening (data not presented). Analysis of the URO produced by the fruit showed that predominantly the typeI isomer was synthesized in extracts from fruit at all stages of development. Only $10 \%$ to $20 \%$ of the total URO was type III, and no consistent trend in the ratio of the two isomers was found as a function of fruit development (data not presented).

Properties of tomato fruit PBG deaminase. $\mathrm{pH}$ and temperature had a pronounced effect on PBG deaminase activity. The enzyme had no activity at $\mathrm{pH} 5.0$, maximal activity at 8.0, and $\approx 15 \%$ of maximal activity at 9.5 . Enzyme activity also was affected by temperature. Maximum enzymatic activity occurred at $57 \mathrm{C}$ and abruptly diminished at $77 \mathrm{C}$. The $\mathrm{Q}_{10}$ was 4.9 for the range 27 to $37 \mathrm{C}, 3.7$ for 37 to $47 \mathrm{C}$, and 1.8 for 47 to $57 \mathrm{C}$. At $77 \mathrm{C}$, the activity was five times greater than at $27 \mathrm{C}$, but only $25 \%$ of the rate at $57 \mathrm{C}$. The rate of production of URO was constant for at least $3 \mathrm{hr}$ during incubation at $37 \mathrm{C}$ and $\mathrm{pH}$ 8.0. The enzyme exhibited typical Michaelis-Menten kinetics with a $K_{m}$ of $17.5 \mu \mathrm{M}$, as calculated from a Lineweaver-Burk plot.

The stability of PBG deaminase was determined by measuring activity at $24-\mathrm{hr}$ intervals during storage at $4 \mathrm{C}$ in the dark in 10 $\mathrm{mM}$ Tris buffer, $\mathrm{pH}$ 7.0. After $24 \mathrm{hr}$ of storage, the enzyme still retained $99 \%$ of its original activity. However, after $48 \mathrm{hr}$, only $66 \%$ of the original activity was present, and it fell to only $27 \%$ after 8 days.

The effects of various sulfhydryl reagents and $\delta$ - aminolevulinic acid (ALA) on PBG deaminase activity were determined (Table 1). Mercury (II) chloride was the most effective inhibitor of the enzyme of the compounds tested, especially at the two lower concentrations (Table 1). $p$-Chloromercuribenzoate at 70 $\mu \mathrm{M}$ was as effective in inhibiting the enzyme as was $\mathrm{HgCl}_{2} . \mathrm{N}$ ethylmaleimide had no effect on enzyme activity at concentrations of 17.5 and $35 \mu \mathrm{M}$, and only a slight inhibitory effect at $70 \mu \mathrm{M}$. ALA increased URO biosynthesis to a small extent, although the difference between 35 and $70 \mu \mathrm{M}$ was smaller than 


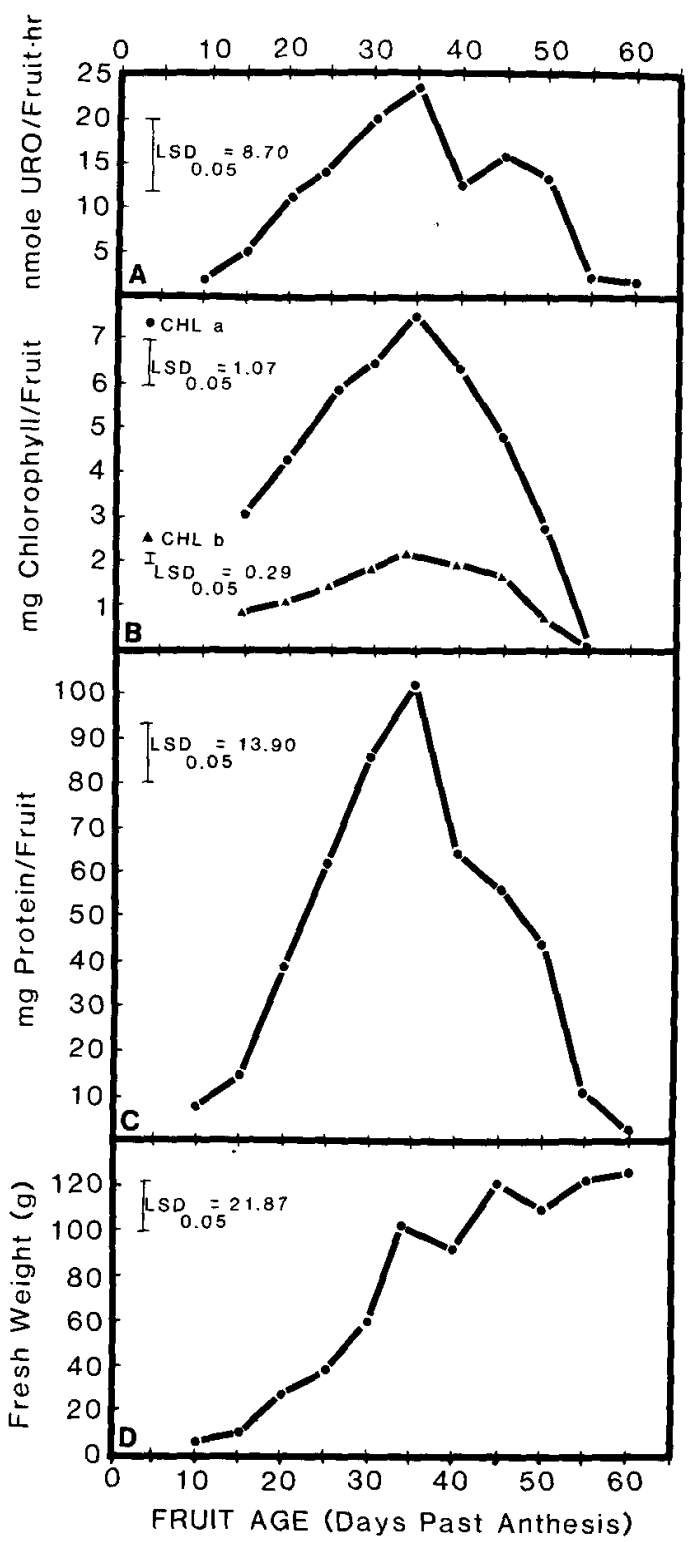

Fig. 1. Effect of fruit age on PBG deaminase activity, chlorophyll content, fruit protein content, and growth pattern expressed on a whole-fruit basis. (A) PBG deaminase activity measured as nmol URO/fruit per hr. (B) Chlorophyll $a$ and $b$ content measured as mg chlorophyll/fruit. (C) Protein content measured as mg protein/fruit. (D) Growth pattern in grams fresh weight.

Table 1. Effect of enzyme inhibitors on PBG deaminase activity.

\begin{tabular}{lccc}
\hline \hline & \multicolumn{3}{c}{ Deaminase activity change ch $^{2} \%$} \\
\cline { 2 - 4 } Enzyme & \multicolumn{3}{c}{ Inhibitor concn $(\mu \mathrm{M})$} \\
\cline { 2 - 4 } inhibitor & 17.5 & 35 & 70 \\
\hline N-ethylmaleimide & 0.0 & 0.0 & -2.0 \\
p-Chloromercuribenzoate & -30.0 & -87.4 & -94.0 \\
$\mathrm{HgCl}_{2}$ & -96.0 & -96.4 & -97.0 \\
$\delta$ - Aminolevulinic acid & +4.5 & +6.9 & +7.7 \\
2-MercaptoethanolY & --- & -100 & -100 \\
\hline
\end{tabular}

${ }^{2}$ Assay conditions described in text. Activity measured as nmol URO/ $\mathrm{hr}$ and expressed as percent changes from the control.

'2-Mercaptoethanol concentrations were 40 and $80 \mu \mathrm{M}$. that between 17.5 and $35 \mu \mathrm{M}$. Curiously, 2-mercaptoethanol completely inhibited the enzyme at 40 and $80 \mu \mathrm{M}$ (Table 1).

\section{Discussion}

Chlorophyll a and $b$ increased in 'Heinz 1350' tomato fruits up to 35 days past anthesis (Fig. 1B). During this same time, PBG deaminase activity increased in a similar manner (Fig. 1A). Chlorophyll content in 40- to 55-day fruits decreased, which may have been due to a greater rate of degradation than biosynthesis. Visually, fruits at this stage of development became much lighter green, indicating chlorophyll degradation.

PBG deaminase was active in extracts of fruit 40 to 50 days past anthesis (Fig. 1A); this supports a hypothesis that there was chlorophyll biosynthesis in fruit of this age. The disappearance of chlorophyll in fruit 55 days past anthesis coincided with an abrupt drop in PBG deaminase activity (Fig.1 A and B). Thus, changes in PBG deaminase activity were similar to changes in chlorophyll content; this implies a relationship between the level of PBG deaminase activity and the rate of chlorophyll biosynthesis in developing tomato fruits. This finding is consistent with that of Frydman and Frydman (1979), who found that pepper and poinsettia leaf PBG deaminase had the greatest activity in young leaves and no activity in senescent leaves. This high activity corresponded to a maximum leaf chlorophyll content, after which the PBG deaminase activity decreased. Because UROGEN III cosynthase activity was constant with respect to leaf age, Frydman and Frydman (1979) concluded that PBG deaminase regulated chlorophyll biosynthesis in leaves. Furthermore, Llambias and Bathe (1971) showed that the rate of chlorophyll biosynthesis was correlated with URO production when dark-grown soybean callus was transferred to light.

The low level of enzyme activity in extracts from ripe fruit (Fig. 1A) was different from Frydman and Frydman's (1979) finding of no detectable activity in extracts from senescent pepper and poinsettia leaves. Thus, ripe tomato fruit tissue has PBG deaminase enzyme capable of limited URO production, although it may not be actively producing URO in ripe tissue.

The decrease in PBG deaminase activity in older fruit could be due to the presence of an inhibitor(s) or to a decrease in the amount of enzyme present within the fruit. The results from mixed extracts from 15-day fruit and ripening or ripe fruit indicate that the measured decline was not due to an inhibitor. Had there been inhibitors present in extracts from ripe fruit, the PBG deaminase activity in the mixed extracts would have been less than additive, and this was not the case. Thus, soluble inhibitors of PBG deaminase were not present, and, probably, the decreased chlorophyll content in ripening or ripe fruit was due to decreased PBG deaminase activity or an accelerated rate of chlorophyll degradation. These results, however, do not preclude the presence of a bound inhibitor that would have been removed with the cellular debris. An inhibitor of this type probably would not cause the measured decrease in PBG deaminase activity observed in this research, but it could limit chlorophyll production.

Changes in protein content were similar to both the changes in PBG deaminase activity and chlorophyll content (Fig. 1 AC). The marked decrease in protein content in fruits $>35$ days past anthesis resulted in low protein contents by 55 and 60 days. Protein content and PBG deaminase activity decreased coincidentally, and the decrease in PBG deaminase activity may have been caused by a decrease in the amount of enzyme in the fruit tissue. Certainly, selective protein breakdown in the fruit tissue may not affect the PBG deaminase enzyme, and the decrease 
in activity may have been caused by other factors. The concurrent declines in chlorophyll content, PBG deaminase activity, and protein content, which began 35 days past anthesis, corresponded with the general decline in fruit growth rate that began between days 35 and 45 (Fig. ID). Thus, the decline of all three of these characteristics may have occurred as fruit growth was completed and ripening events were initiated.

Small amounts of URO III (the precursor of chlorophyll) in the extracts showed that URO III cosynthase also was present with the PBG deaminase enzyme. Unless the cosynthase is highly purified. and present in excess with respect to the PBG deaminase, URO I is the major product of the reaction (Frydman et al., 1979). Furthermore, URO III cosynthase activity can decrease in vitro, even when present in excess, and this leads to obvious difficulties in attempting accurate assay of the enzyme (Burnham and Bachmann, 1979).

Our research showed that there was a relationship between the changes in chlorophyll content, PBG deaminase activity, and protein content during tomato fruit ontogeny. All three of these aspects increased to a maximum value at 35 days past anthesis, then decreased to near zero upon ripening and senescence. These data suggest that PBG deaminase has a regulatory role in chlorophyll biosynthesis in tomato fruits.

\section{Literature Cited}

Bradford, M.M. 1976. A rapid and sensitive method for the quantitation of microgram quantities of protein utilizing the principle of protein-dye binding. Anal. Biochem. 72:248-254.

Brodie, M. J., M.R. Moore, G.G. Thompson, B.C. Campbell, and A. Goldberg. 1977. Is porphobilinogen deaminase a secondary control mechanism in heme biosynthesis in humans? Biochem. Soc. Trans. 5:1466-1468.

Burnham, B.F. and R.C. Bachmann. 1979. Enzymatic synthesis of porphyrins, p. 234-257. In: D. Dolphin (cd.). The porphyrins, vol. 6. Biochemistry, Part A. Academic, New York.

Castelfranco, P.A. and S.I. Beale. 1983. Chlorophyll biosynthesis: Recent advances and areas of current interest. Annu. Rev. Plant -Physiol. 34:241-278.
Englert, E., Jr., A.W. Wayne, E.E. Wales, Jr., and R.C. Straight. 1979. A rapid, new and direct method for isolation and measurement of porphyrins in biological samples by high performance liquid chromatography. J. High Res. Chromatogr. Chromatogr. Commun. 2:570574.

Frydman, R.B. and B. Frydman. 1979. Disappearance of porphobilinogen deaminase activity in leaves before the onset of senescence. Plant Physiol. 63:1154-1157.

Frydman, R. B., B. Frydman, and A. Valasinas. 1979. Protoporphyrin: synthesis and biosynthesis of its metabolic intermediates, p. 1-124. In: D. Dolphin (cd.). The Porphyrins, vol. 6. Biochemistry, Part A. Academic, New York.

Harel, E. 1978. Chlorophyll biosynthesis and its control. Prog. Phy tochem. 5:127-180.

Hobson, G.E. 1967. Phenolase activity in tomato fruit in relation to growth and to various ripening disorders. J. Sci. Food Agr. 18:523526.

Jordan, P.M. and D. Shemin. 1973. Purification and properties of uroporphyrinogen I synthetase from Rhodopseudomonas spheroids. J. Biol. Chem. 248: 1019-1024.

Llambias, E.B.C. and A.M. del C. Bathe. 1971. Studies on the porphobilinogen deaminase-uroporphyrinogen cosynthase system of cultured soya-bean cells. Biochem. J. 121:327-340.

Lyons, J.M. and H.K. Pratt. 1964. Effect of stage of maturity and ethylene treatment on respiration and ripening of tomato fruits. Proc. Amer. Soc. Hort. Sci. 84:491-500.

Martin, B. A., J.A. Gauger, and N.E. Tolbert. 1979. Changes in activity of ribulose-1, 5-bisphosphate carboxylase/oxygenase and three peroxisomal enzymes during tomato fruit development and ripening. Plant Physiol. 63:486-489.

Mayer, A.M. and E. Harel. 1981. Polyphenol oxidases in fruits-changes during ripening, p. 161-180. In: J. Friend and M.J. Rhodes (eds.). Recent advances in the biochemistry of fruits and vegetables. Academic, London.

McMahon, R.W. and R.J. Gladon. 1984. Method for extraction and quantitation of chloroplast pigments in fruits and other organs by high performance liquid chromatography. HortScience 19:220221

Wayne, A. W., R.C. Straight, E.E. Wales, and E. Englert, Jr. 1979. Isomers and uroporphyrin free acids separated by HPLC. J. High Res. Chromatogr. Chromatogr. Commun. 2:621-622. 